\title{
Een juridische bypass voor innovaties
}

\author{
S. Philipsen \& E.F. Stamhuis
}

\section{Inleiding}

Het juridische experiment staat in het middelpunt van de belangstelling. In het regeerakkoord dat eind 2017 het licht zag, werd al een groot aantal experimenten aangekondigd. ${ }^{1}$ Inmiddels zijn de eerste van die plannen in wetsvoorstellen omgezet. De Experimentenwet rechtspleging is daarvan een voorbeeld. Aan andere experimenten werd al veel langer gewerkt. Dat geldt bijvoorbeeld voor het voorstel voor de regeling om zelfrijdende auto's experimenteel op de openbare weg toe te laten, dat reeds bij de Eerste Kamer aanhangig is. ${ }^{2}$ Naast deze wetgevingsactiviteiten was experimenteerwetgeving vorig jaar het onderwerp van de jaarvergadering van de Nederlandse Vereniging voor Wetgeving. En enkele weken voor die bijeenkomst sprak Jacobs in Amsterdam haar oratie uit met de titel: 'Experimentele wetgeving'. Over aandacht heeft het juridische experiment dus niet te klagen. ${ }^{3}$

Juridische experimenten komen in verschillende gedaanten voor. Zo kunnen experimenten rechtstreeks gebaseerd zijn op een wettelijk voorschrift. Dergelijke experimenteerbepalingen bieden de overheid expliciet de mogelijkheid om van het geldende wettelijk kader af te wijken. Een van de belangrijkste toepassingsdoelstellingen van deze afwijkingsmogelijkheid is het faciliteren van innovatie. Experimenteerbepalingen zijn evenwel niet het enige middel dat dit doel kan bewerkstelligen. Een ander instrument dat steeds vaker wordt toegepast om innovatie te faciliteren, maar dat in de juridische literatuur nog weinig aandacht kreeg, is de regulatory sandbox.

Anders dan bij experimenten die gebaseerd zijn op een experimenteerbepaling zijn experimenten in de vorm van regulatory sandboxes niet op een specifieke wettelijke grondslag terug te voeren. Bij regulatory sandboxes wordt de bestaande wetgeving vooral op een andere wijze toegepast, om zo innovatie te bevorderen. Het gebruik van zowel experimenteerbepalingen als regulatory sandboxes roept een groot aantal juridische vragen op.

De belangrijkste vragen komen voort uit het feit dat beide instrumenten uitzonderingen op (de toepassing van) bestaande regels maken die slechts voor een beperkte groep van gevallen of situaties gelden. In deze bijdrage zullen wij om die reden nader ingaan op zowel de experimenteerbepalingen als regulatory sand-

1 M.J. Jacobs, Experimentele wetgeving (oratie Amsterdam VU), Deventer: Wolters Kluwer 2018, p. 8; zie ter illustratie het regeerakkoord, 'Vertrouwen in de toekomst', p. 5.

2 Vgl. Kamerstukken II 2013/14, 31305, 210; Kamerstukken I 2017/18, 34838, A-C.

3 Het eerste integrale onderzoek in Nederland naar experimenten in het recht werd verricht door Ranchordás, zie S.H. Ranchordás, Sunset Clauses and Experimental Legislation (diss. Tilburg), 2014. Voor Vlaanderen: SERV, Experimenteerwetgeving en regelluwe zones, Brussel 2016, p. 15. 
boxes, voor zover die instrumenten worden gebruikt bij het faciliteren van innovatie. Ons doel daarbij is een set vuistregels te ontwikkelen die behulpzaam kan zijn om tijdig juridische voetangels en klemmen te identificeren en te ontwijken. De vuistregels bieden ondersteuning bij de vormgeving van het besluit om experimenten toe te staan. Een gedetailleerde, sectorgebonden studie zal daarover ongetwijfeld nog meer uitkomsten bieden dan wij nu in dit algemene bestek leveren. Ons gaat het nu om de gemeenschappelijke aspecten. Daarnaast geldt dat de hierna te bespreken instrumenten voor experimenteren door ons vooral in een juridische context worden beschouwd. ${ }^{4}$ Naast juridische gezichtspunten kunnen er bij experimenten vaak ook politieke, methodologische en ethische kanttekeningen worden gemaakt. ${ }^{5}$ Die zullen in deze bijdrage niet in extenso worden besproken.

In de navolgende paragraaf zullen wij het onderzoeksobject eerst nader definiëren en afbakenen. Vervolgens bevatten paragraaf 3 en 4 een meer gedetailleerde beschrijving van respectievelijk de experimenteerbepaling en de regulatory sandbox. In paragraaf 5 komen wij tot de kern, wanneer wij ingaan op de juridische vragen die het gebruik van zowel experimenteerbepalingen als regulatory sandboxes oproept, om vervolgens in paragraaf 6 het saldo op te maken in de vorm van de hulpmiddelen voor de juridische afwegingen. Paragraaf 7 geeft een afsluitende slotsom van het betoog.

\section{Nadere afbakening}

In veel landen volgen overheden ${ }^{6}$ het OESO-credo, dat innovaties goed zijn voor de economie. ${ }^{7}$ Dat vormt de drijfveer om door middel van beleid en regelgeving ruimte te geven aan de introductie van nieuwe producten en diensten. ${ }^{8}$ Van dit credo vinden we tevens een niet-economische variant. Dan wordt de innovatie vooral gevonden in een betere realisatie van beleidsdoelen op een bepaald terrein. Ook dat zet ertoe aan om vanuit de overheid zo veel mogelijk welwillendheid voor vernieuwing in te bouwen in de behartiging van dat betreffende beleidsterrein. Ruimte geven aan innovatie kan door een actief ingrijpen in regels of daarop

4 A. Butenko \& P. Larouche, 'Regulation for Innovativeness or Regulation of Innovation?', Law, Innovation and Technology (7) 2015, afl. 1, p. 52-82, op p. 57 e.v.

5 Zie voor enkele van die kanttekeningen T. Buyse, P. van Humbeeck \& J. van Nieuwenhove, 'Ervaringen met experimentwetgeving in Vlaanderen', in: V.I. Daskalova \& M.A. Heldeweg (red.), Constitutionele mogelijkheden en beperkingen voor experimenteel handelen en experimentele wetgeving, Nijmegen: Wolf Legal Publishers 2016, p. 97.

6 Overheden is hier ruim bedoeld. Daaronder worden niet alleen regelgevende overheidsorganen, maar ook uitvoeringsinstanties verstaan.

7 Zie OECD, The Innovation Imperative. Contributing to Productivity, Growth and Wellbeing, 2015, p. 17, https://read.oecd-ilibrary.org/science-and-technology/the-innovation-imperative/the-roleof-innovation-and-the-rationale-for-public-policy_9789264239814-3-en (laatst geraadpleegd op 12 februari 2019). Ranchordás plaatst een vraagteken bij de empirische basis voor deze stelling, Ranchordás 2014, p. 20. De OECD spreekt over 'complex empirical links' tussen innovatie en groei.

8 Wanneer hierna wordt gesproken over 'product' wordt in ieder geval ook altijd 'dienst' bedoeld, tenzij 'dienst' expliciet toegevoegd wordt. 


\section{Figuur 1 Experimenten in model}

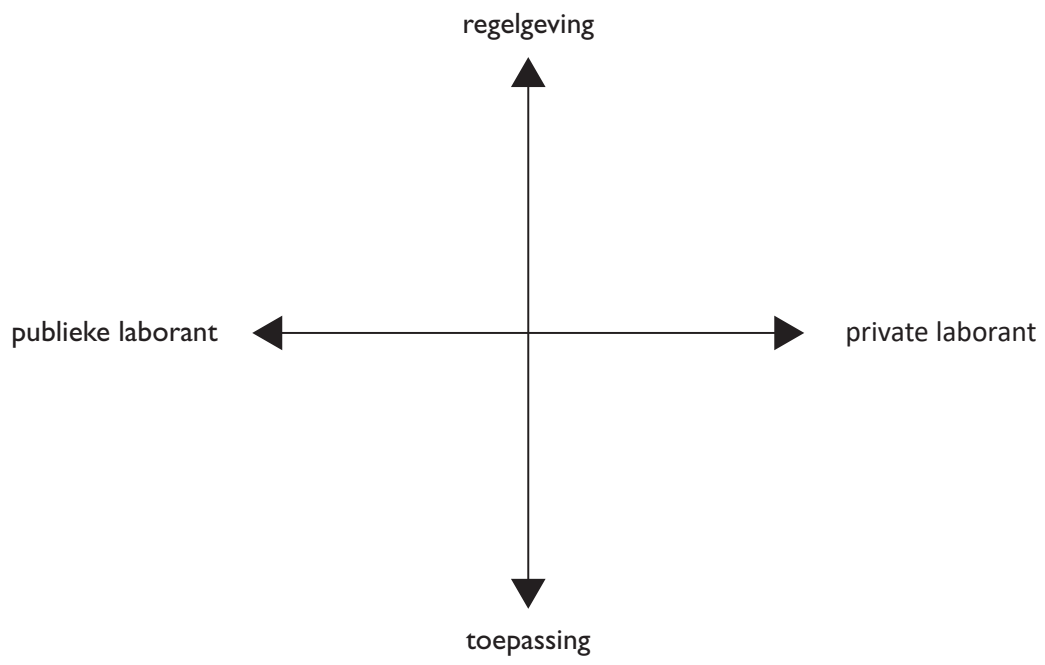

gebaseerd (uitvoerings)beleid, het kan ook door juist niets te regelen. In deze bijdrage gaan wij uitsluitend in op situaties waarin de overheid actief ingrijpt, met als doorslaggevende reden dat de Nederlandse overheid zich nadrukkelijk actief opstelt.

De verschijningsvormen van juridische experimenteerruimte zijn onderling divers. Om ze helder te kunnen beschrijven en de omvang van deze bijdrage daarmee nader af te kunnen bakenen, helpt het om de verschillende verschijningsvormen met behulp van twee elkaar kruisende assen ten opzichte van elkaar te ordenen. Die twee assen zijn hieronder in figuur 1 weergegeven en worden daarna toegelicht.

De verticale as representeert de juridische verschijningsvorm van het gehanteerde instrument in het spectrum tussen de twee juridische ideaaltypen: regelgeving en individuele toepassing. Daaruit blijkt dat experimenten zowel door de uitvoerende instantie als door de wetgever kunnen worden geëntameerd. Van experimenten die gelegen zijn op het uiterste boven aan de verticale as is het kenmerk dat voor het experiment een wettelijke grondslag gecreëerd wordt, waarbij bestaande normen voor een bepaalde duur terzijde worden geschoven en worden vervangen door andere normen. Het andere uiterste, onderaan op dezelfde as, betreft het geval waarin de geldigheid van de toepasselijke normen in het individuele geval tijdelijk wordt opgeschort. Weinig verrassend is dat experimenten die op deze as boven het kruispunt zitten tot ontwikkeling gekomen zijn bij de centrale overheidsorganen die regelgevende bevoegdheid hebben, zoals de formele wetgever en de regering. Experimenten onder het kruispunt zien we meer in het domein van de autoriteiten die met handhaving en toezicht belast zijn; in de praktijk met name de toezichthouders op een gereguleerde markt. Voor alle posi- 
ties op deze as geldt evenwel dat in het concrete geval een uitzonderlijk rechtsregime voor beperkte tijd gerealiseerd wordt. Dat het in de praktijk zal gaan om een positie ergens tussen deze twee uitersten en nauwelijks om conceptueel zuivere vormen, kunnen we mooi met het gedrag van de genoemde toezichthouders laten zien. Ze zijn zelden competent om de regels waaraan zij zelf gebonden zijn (tijdelijk) te veranderen, maar kunnen in het kader van de opschorting van de werking ervan wel nadere gedragsnormen formuleren voor de fase van de uitvoering van het experiment. Er wordt dus ook dan een tot op zekere hoogte gewijzigde regeltoestand voor het concrete geval in het leven geroepen. Ook voor experimenten die gebaseerd zijn op een wettelijke experimenteerbepaling geldt vaak dat het experiment in de praktijk pas daadwerkelijk plaats kan vinden nadat het bestuur de kaders waarbinnen het experiment moet plaatsvinden nader heeft omlijnd.

Van een andere orde is de horizontale as tussen enerzijds gevallen waarin de overheidsinstantie zelf als de laborant optreedt en anderzijds gevallen waarin private actoren veroorloofd wordt te experimenteren. Links van het kruispunt liggen de door de overheid uitgevoerde experimenten met een veranderde toestand van de regels, regulering met een andere inhoud of juist minder regels. Men denke aan het experiment met de regelluwe school. De vraag voor dit experiment is dan hoe 'het veld' zal reageren op deze nieuwe regeltoestand. Op het moment dat de overheid zelf experimenteert, start het experiment al meteen nadat de wijziging van de regels of een aanpassing van het beleid van kracht geworden is. Dat is anders wanneer wetgeving en beleid ruimte bieden aan experimenten door private actoren. Dan creëert de overheid slechts de voorwaarden, maar vindt het experiment pas plaats als daartoe (voldoende) privaat initiatief wordt genomen. Een voorbeeld van experimenten ter rechterzijde van het kruispunt zien we in de situatie dat aan producenten van volledig zelfrijdende voertuigen vergunning wordt verleend om die zelfrijdende voertuigen aan het wegverkeer te laten deelnemen. Een ander voorbeeld van rechts op de horizontale as geplaatste experimenten is de casus dat de toezichthouder aan een nieuwe financiële aanbieder tijdelijk toestaat om een bepaald product op de markt te brengen.

De diverse praktijksituaties zijn met behulp van de kruisende assen in figuur 1 ten opzichte van elkaar te positioneren door plaatsing ergens in een van de vier kwadranten. Wij concentreren ons in deze bijdrage op de gevallen waarin aan private actoren een tijdelijke rechtsruimte geboden wordt om met een product te experimenteren, waarvan tevoren aangenomen wordt dat dit zonder toepassing van het instrument ongeoorloofd is. Dat zijn experimenten die vooral in het kwadrant rechtsboven en rechtsonder thuishoren. In paragraaf 3 bespreken we de experimenteerbepalingen die vooral in het kwadrant rechtsboven geplaatst kunnen worden. De sandboxes die in paragraaf 4 aan de orde komen, positioneren we dan in het kwadrant rechtsonder.

Wanneer experimenteerruimte wordt gecreëerd om private actoren in het ontwikkelingsproces van een nieuw product of nieuwe dienst te faciliteren, kan dat in iedere fase van het ontwikkelingsproces. In algemene zin laten zich twee verschil- 
lende toepassingsmodaliteiten onderscheiden. ${ }^{9}$ Ten eerste is er het proactieve gebruik dat vooral tot doel heeft innovatie uit te lokken. De experimenteerruimte wordt dan vooral ingezet als pr-instrument en moet een positief innovatieklimaat uitstralen. Op het moment van invoering hoeft een concrete behoefte aan experimenteerruimte nog niet te zijn gebleken. Leidende gedachte is dat de beschikbaarheid van de instrumenten innovators aantrekt om onder dat aangekondigde regime vernieuwingen uit te proberen. Ten tweede kan de overheid experimenteerruimte ook reactief inzetten. Daarvan is vooral sprake als het bedrijfsleven om verruiming van de juridische kaders vraagt. Een dergelijk verzoek wordt bijvoorbeeld gedaan door bedrijven die bij de ontwikkeling van een nieuw product of dienst de inschatting maken dat het geldende juridisch kader ongewenste of onoverkomelijke beperkingen oplevert voor de ontwikkeling. Daarnaast kan het reactief gebruik van experimenteerruimte ook volgen op een door de overheid gedane constatering dat het geldende juridisch kader onoverkomelijke problemen met zich brengt voor een nieuw product. Meestal zal die constatering volgen op de introductie van het product. Als de overheid het innovatieve product in beginsel toelaatbaar acht, kan met gebruik van experimenteerruimte tijd gewonnen worden voor het vinden van een juiste en definitieve reguleringsmodaliteit.

Ontwikkelaars van innovatieve producten willen in de regel zo snel mogelijk duidelijkheid omtrent de juridische toelaatbaarheid van het door hen ontwikkelde nieuwe product. Dat geldt in het bijzonder wanneer het in een (sterk) gereguleerde context aangeboden gaat worden. Onzekerheid over het van toepassing zijnde juridisch kader brengt immers financiële risico's met zich. De aanbieder kan gewoon de markt op gaan en afwachten wat de overheid gaat doen, maar dat is nogal riskant. Er is al (veel) geld en energie in de ontwikkeling gestoken en dat zou verloren gaan als het product rechtens ontoelaatbaar zou blijken te zijn. ${ }^{10}$ Opmerking verdient dat in alle fasen van het ontwikkelingsproces van ieder innovatief product nooit in een juridisch vacuüm wordt geopereerd. Bij gebreke van specifieke wettelijke normen zijn daar altijd de algemene regels en beginselen uit het civiele recht, het (internationale) handelsrecht, het strafrecht en de grondrechten, die het handelen normeren. ${ }^{11}$

9 Vgl. E. Fosch Villaronga \& M.A. Heldeweg, 'Regulering voor experimenten met emergente robottechnologie', in: I. Daskalova \& M.A. Heldeweg (red.), Constitutionele mogelijkheden en beperkingen voor experimenteel handelen en experimentele wetgeving, Nijmegen: Wolf Legal Publishers 2016, p. 90-97.

10 Zie over de verschillende ontwikkelingsfasen Fosch Villaronga \& Heldeweg 2016. Kaal signaleert het belang van een vroeg signaal, in W.A. Kaal, 'Dynamic Regulation for Innovation', in: M. Corrales, M. Fenwick \& H. Haapio (red.), Perspectives in Law, Business and Innovation, n.n.g., p. 17.

11 G. Wagner, Robot Liability, 2018, p. 6, noemt de algemene juridische kaders terecht de werkpaarden van het recht, zie https://ssrn.com/abstract=3198764 (laatst geraadpleegd op 12 februari 2019). In dit licht ervaren wij de soms fortissimo geponeerde stelling dat het recht slechts als een schildpad op de haas van de ICT-ontwikkelingen reageert als tamelijk eenzijdig; zie o.m. Butenko \& Larouche 2015, p. 66, die ons inziens ten onrechte spreken over 'regulatory void'; overgenomen door M.D. Fenwick, W.A. Kaal \& E.P.M. Vermeulen, 'Regulation Tomorrow: What Happens When Technology Is Faster Than the Law?', American University Business Law Review (6) 2017, afl. 3, p. 568. Ongelukkigerwijs wordt dat schildpad-haasframe ook gebruikt in de bestseller van Y.N. Harari, Homo Deus, Londen: Vintage 2017, p. 436. 
Niet zelden is een innovatie als zodanig nog niet in toegesneden regels gevangen, maar deelaspecten van het innovatieve product of de innovatieve dienst wel. Of bestaande regels op (een deel van) het innovatieve product van toepassing zijn, hangt af van de vraag hoe het nieuwe fenomeen in het licht van de bestaande regelgeving gekwalificeerd moet worden. Uber als fenomeen was niet specifiek geregeld, maar op commercieel personenvervoer en op arbeidsverhoudingen waren wel al regels van toepassing. Voor Airbnb gold iets dergelijks: voor deze nieuwe vorm van bij onbekenden tegen vergoeding 'logeren' was geen speciale regeling beschikbaar, maar het tegen betaling bieden van een overnachtingslocatie is op vele plaatsen in de wereld wel in regels gevangen. ${ }^{12}$ Autonome voertuigen waren als zodanig niet in de regels erkend, maar de verkeersveiligheid werd en wordt wel met allerlei geboden en verboden behartigd, evenals de onderlinge aansprakelijkheid bij een ongeval.

De waarde van experimenteerruimte schuilt niet alleen in het veronderstelde vermogen om een goed innovatieklimaat te bevorderen. Het bieden van experimenteerruimte stelt de overheid tevens in staat om proefondervindelijk te beoordelen of en op welke wijze een innovatief product of een sector in de toekomst het best gereguleerd kan worden. Door experimenteerruimte te bieden kan de overheid de wetgevingskwaliteit in de moderne complexe en dynamische samenleving verbeteren, door tot meer evidence based en toekomstbestendige wetgeving te komen. ${ }^{13}$ Experimenteerruimte introduceert feedbackmechanismen die onder andere de overheid in staat stellen informatie te verkrijgen over functionaliteit en externaliteiten van het nieuwe product of de nieuwe wijze van reguleren. Deze feedbackmechanismen moeten leiden tot een zo goed mogelijke regulering in de toekomst. Tegelijkertijd moet worden onderkend dat de beslissing om experimenten in reallife omstandigheden toe te staan, niet volledig samenvalt met de vraag hoe het product in de toekomst moet worden gereguleerd. Die laatste vraag zal na afloop van het experiment pas een definitief antwoord (kunnen) krijgen.

De onzekerheid die inherent is aan experimenteren en de aard van het experiment als een beperkte uitzondering op (de toepassing van) bestaande regels leiden tot een aantal specifieke juridische vragen. Juridische-experimentfaciliteiten hebben gemeenschappelijk dat gedurende een beperkte tijd ten behoeve van een beperkt aantal actoren - soms maar één - een juridisch regiem van toepassing is dat verschilt van dat wat voor de overige actoren geldt. Het probleem van deze instrumenten is dat zij op gespannen voet kunnen komen te staan met juridische kernwaarden, bijvoorbeeld verwoord in de beginselen van behoorlijke wetgeving en behoorlijk bestuur. Gelijkheid, kenbaarheid en voorspelbaarheid van het overheidshandelen komen daarin in verschillende gedaantes tot uitdrukking. De toepassing van een verschillend juridisch regiem op een beperkte groep gedurende een beperkte tijd levert potentieel ongelijkheid, gebrekkige kenbaarheid en min2016, afl. 2, p. 102-116.

13 Zie voor het streven naar toekomstbestendige wetgeving Kamerstukken II 2015/16, 33009, 9. 
der voorspelbaarheid op. ${ }^{14}$ Hierna zullen wij eerst de experimenteerbepaling en de regulatory sandbox als fenomenen in de praktijk beschrijven, waarna we zullen terugkeren naar de juridische kaders die voor beide experimenteermogelijkheden gelden. Die kaders zullen wat ons betreft uitmonden in de bespreking van vuistregels voor de beslissing tot toelating van het experiment, niet zozeer in de algemene vraag of experimenteren generiek toelaatbaar of verstandig is.

\section{Experimenteerbepalingen}

In de gangbare definitie worden experimenteerbepalingen omschreven als bepalingen die een bevoegdheid bieden om bij wijze van experiment van bestaande regelgeving af te wijken. ${ }^{15}$ De Aanwijzingen voor de regelgeving (Ar) definiëren een experiment als het 'proefondervindelijk vaststellen of een bepaald instrument een bijdrage levert aan het oplossen van een maatschappelijk probleem'. ${ }^{16}$ Daarbij schrijven de Aanwijzingen voor dat experimenteerbepalingen slechts een grondslag mogen bieden voor regelgeving waarvan de werking naar tijd en plaats beperkt is. Ook dient vooraf het doel van het experiment voldoende duidelijk te zijn omschreven en moet het experiment achteraf altijd worden geëvalueerd. ${ }^{17}$

Een van de eerste beleidsterreinen waarop experimenteerbepalingen in Nederland werden toegepast, was het onderwijs. ${ }^{18}$ Inmiddels komen zij in een groot aantal verschillende wetten en op allerlei beleidsterreinen voor. Zeer bekend is artikel 2.4 van de Crisis- en herstelwet, dat het mogelijk maakte om bij wijze van experiment van tal van wetten af te wijken om innovaties te bevorderen die zouden bijdragen aan het bestrijden van de economische crisis.

Bij de experimenten in het onderwijs gaat het bijna altijd om experimenteren met wetgeving. Dat zijn de experimenten aan de linkerzijde van de verticale as in figuur 1. De overheid vervult dan zelf de rol van laborant. We noemden al het voorbeeld van de regelluwe school. ${ }^{19}$ Een ander voorbeeld bieden de voorgenomen projecten voor de civiele rechtspraak, waarvoor de Experimentenwet rechtspleging in de maak is. ${ }^{20}$ Deze vorm van experimenteren met wetgeving is de klassieke vorm van experimenteerwetgeving, waarop de hierboven genoemde definities en kwaliteiten uit de Aanwijzingen voor de regelgeving betrekking hebben. Experimenten met wetgeving zijn in essentie beleidsexperimenten. Zij

14 S. Ranchordás, 'Experimentwetgeving: pad naar innovatie of de democratische rechtstaat onder druk?', in: Preadviezen 2018: Experimentwetgeving (Jaarvergadering Nederlandse Vereniging voor Wetgeving), Den Haag: NVvW 2018, p. 30-32.

15 S. Ranchordás, 'Experimentwetgeving: een regelluwe zone?', in: V.I. Daskalova \& M.A. Heldeweg (red.), Constitutionele mogelijkheden en beperkingen voor experimenteel handelen en experimentele wetgeving, Nijmegen: Wolf Legal Publishers 2016, p. 15.

16 Ar 2.41.

17 Vgl. Ar 2.41 en 2.42

18 Jacobs 2018, p. 13.

19 E. Florijn, 'Paden naar Utopia. Over regels, regeldruk en experimenten in het onderwijs', RegelMaat 2016, afl. 2, p. 118-119.

20 Zie P. Ingelse, 'Experimentenwet: carte blanche verdient nadere overweging', Tijdschrift voor Civiele Rechtspleging 2018, afl. 3, p. 55-64. 
bieden een grondslag om te beoordelen of nieuwe regels, dan wel minder regels, tot hetzelfde of een beter resultaat leiden in vergelijking met de geldende regelgeving. Daarvoor wordt meestal een deel van de rechtssubjecten die onder de oorspronkelijke regel vielen in een experimentele groep ondergebracht. Deze experimentele groep wordt aan de nieuwe regelgeving blootgesteld. De overige rechtssubjecten vallen in de controlegroep. Wezensbestanddeel van het experiment met wetgeving is dan ook de evaluatie. De evaluatie stelt de regelgever namelijk in staat om na afloop te besluiten of de nieuwe regelgeving op iedereen van toepassing zal worden verklaard. Dit type beleidsexperimenten is een vorm van 'ex-antecontrole van wetgeving to be'. ${ }^{21}$

De experimenten die in deze bijdrage centraal staan, kunnen het best worden gekarakteriseerd als experimenteren door wetgeving. Deze experimenten beogen ook tot betere regelgeving te leiden, maar zijn daarnaast vooral ook verbonden met de ontwikkeling en introductie van een innovatief product. De ontwikkeling van innovaties vereist dat zij op enig moment aan real-life omgevingen worden blootgesteld. ${ }^{22}$ Anders dan bij de experimenten met wetgeving, staat bij experimenten door wetgeving vaak vast dat de rechtstoestand niet ongewijzigd kan blijven. De regelgever heeft echter te weinig informatie over het te reguleren product om adequate regelgeving al onmiddellijk tot stand te brengen. Experimenteerbepalingen bieden zo een grondslag om de onzekerheid die eigenlijk altijd met regulering gepaard gaat, maar die in het bijzonder samenvalt met de regulering van innovatieve ontwikkelingen, te reduceren door tezamen met de ontwikkelaar de impact van het innovatieve product op beperkte schaal te ontdekken. ${ }^{23}$ Daarmee passen experimenteerbepalingen goed in de trend om interactief en evidence based tot wettelijke regelingen te komen, zonder dat daarmee de regeldruk onnodig wordt vergroot. De term smart regulation wordt in dit kader ook wel als containerbegrip gehanteerd. ${ }^{24}$ Die regulering komt 'zoekend en lerend' tot stand in plaats van voor eens en altijd. ${ }^{25}$ Het concept smart regulation verwijst naar diverse vormen van responsief reguleren of adaptieve wetgeving. Het betreft een variant van regelvorming, vaststelling en implementatie, die is gegroeid als antwoord op de toegenomen complexiteit van de te reguleren materie bij een terugtredende overheid. De aanname is dat regulering beter wordt wanneer de maatschappelijke actoren met hun specifieke materiekennis deelnemen in dat proces, waardoor dat als vanzelf evolueert van eenzijdige regelafkondiging (command-and-control regula-

21 SERV 2016, p. 19. Het verschil in context tussen dit type experimenten en de tweede groep hierna te bespreken experimenten is naar ons oordeel te groot om onze beschouwingen in deze bijdrage een-op-een toepasbaar te achten op experimenten met wetgeving. Juridische vuistregels zijn voor die experimenten evengoed heel relevant, maar zien er vermoedelijk anders uit. We laten het dan ook bij deze vluchtige notities.

22 SERV 2016, p. 26-27.

23 Zie voor een volledig overzicht Ranchordás 2014, p. 84-103.

24 N. Gunningham \& D. Sinclair, 'Smart Regulation', in P. Drahos (red.) Regulatory Theory. Foundations and Applications, Canberra: Australian National University Press 2017; J. Hanebury, 'Smart Regulation - Rhetoric or Reality', Alberta Law Review (44) 2006, afl. 1, p. 33-63. 
tion) naar interactieve normvorming en toepassing van een mix aan reguleringsvarianten. ${ }^{26}$

\section{De regulatory sandbox}

Een volgende loot aan de stam van juridische instrumenten die experimenten mogelijk moeten maken, is de regulatory sandbox. Vrij algemeen wordt de Britse financiële toezichthouder (FCA) de lof toegezwaaid de primeur met dit instrument te hebben gehad. ${ }^{27}$ De FCA lanceerde het initiatief in juni 2016, waarna stap voor stap de collega-toezichtautoriteiten in andere landen volgden. In de eerste maanden van 2018 leek het haast alsof er geen week voorbijging zonder dat een nationale overheid ergens in de wereld zich (vergezeld van de nodige bombarie) in deze rij voegde, kennelijk in een wedloop om de meest innovatieve economie van de regio te zijn. ${ }^{28}$ Onze eigen financiële toezichthouders de Autoriteit Financiële Markten (AFM) en De Nederlandsche Bank (DNB) passen de regulatory sandbox toe sinds 1 januari 2017 in een gezamenlijk actieprogramma 'Maatwerk voor innovatie'. De fintechmarkt is de broedmachine geweest voor dit instrument, maar het wordt daartoe internationaal niet beperkt. Sommige economieën in Azië bijvoorbeeld maken de toepassing heel breed door expliciet de verbinding met de innovatie op het gebied van gezondheidszorg ${ }^{29}$ en agrobusiness $^{30}$ te leggen.

De regulatory sandbox is in wezen geen reguleringsvorm, maar een beleidslijn voor de handhaving van de toepasselijke regelingen. Het begrip sandbox is afkomstig van de ontwikkelaars van software en games en verwijst naar een speelruimte waar de rules of the game niet gelden en nieuwe probeersels kunnen worden getest. De gebruikers kunnen binnen zeer ruime kaders gedurende een bepaalde periode hun gang gaan. Al spelend/testend genereren ze feedback op het ontwikkelde (half)fabricaat, die bruikbaar is voor de beslissing tot voortgezette toepassing, aanpassing of stopzetting.

26 Gunningham \& Sinclair 2017, p. 134; D. Zetzsche e.a., 'Regulating a Revolution: From Regulatory Sandboxes to Smart Regulation', Fordham Journal of Corporate \& Financial Law (23) 2017, p. 31-103; S. di Castri \& A. Plaitakis, Going Beyond Regulatory Sandboxes to Enable FinTech Innovation in Emerging Markets, 23 januari 2018. Online beschikbaar via http://dx.doi.org/10.2139/ssrn. 3059309 (laatst geraadpleegd op 12 februari 2018).

27 Toronto Centre, Regulatory Sandboxes (TC Notes), november 2017, p. 3, verwijst naar een initiatief van het US Consumer Financial Protection Bureau in het jaar 2012, waarvoor de term regulatory sandbox niet gehanteerd werd, maar wat wel op hetzelfde neerkwam. De FCA was niettemin de eerste met het initiatief onder deze vlag.

28 De ontwikkeling naar een grensoverschrijdende toepassing is ingezet door de FCA. Zie FCA, Global Financial Innovation Network (GFIN) (Consultation document), augustus 2018; officiële lancering januari 2019. Zie www.fca.org.uk/firms/global-financial-innovation-network (laatst geraadpleegd op 20 februari 2019).

29 Zie www.moh.gov.sg/our-healthcare-system/licensing-experimentation-and-adaptation-programme-(leap)---a-moh-regulatory-sandbox voor het testen van telemedicine in Singapore (laatst geraadpleegd op 12 februari 2019).

30 Zie www.thestar.com.my/business/business-news/2018/02/14/mof-implements-national-regulatory-sandbox-initiative/ (laatst geraadpleegd op 12 februari 2019), waarin voor Maleisië een wel heel breed gamma van toepassingen genoemd wordt. 
In de sandbox zet de regulatory body - in onze termen: de marktautoriteit - een juridische ruimte apart om met innovatieve producten te kunnen experimenteren, waarbij de beperkingen van de regels in hun gangbare toepassing tijdelijk worden opgeschort. Dat apart zetten gebeurt in beginsel op een case-by-case basis ten behoeve van aanbieders van het innovatieve product, maar de details verschillen van land tot land. Om een vergelijkend voorbeeld uit het domein van fintech te geven: de Australian Securities \& Investments Commission propageert een class waiver voor aanbieders die nog geen vergunning hebben, maar die toch in de markt een nieuw financieel product willen testen. ${ }^{31}$ De nieuwkomer moet aan een aantal voorwaarden voldoen, maar hoeft zich alleen maar voor dit uitzonderingsprogramma aan te melden. Zonder tegenbericht mag dan twaalf maanden zonder vergunning worden getest. De Nederlandse AFM/DNB-combinatie gaat uit van individuele arrangementen, vandaar dat het gezamenlijke actieprogramma de titel 'Maatwerk voor innovatie' meekreeg. ${ }^{32}$ De Britse FCA maakt ook concrete afspraken rond een specifieke test, waarin de volgende componenten concreet verwerkt kunnen worden. Deze zijn representatief voor wat bij andere toepassingen is aangetroffen: ${ }^{33}$

- toegangverlening tot de markt voor de precies omschreven testsituatie (relevant voor start-ups of voor een innovatieve uitbreiding van het productaanbod door een gevestigde aanbieder, die niet bestreken wordt door de aanwezige vergunning);

- $\quad$ explicitering van de interpretatie van op de testsituatie toepasselijke regels;

- verklaring dat bepaalde regels niet of slechts op een bepaalde wijze toegepast zullen worden;

- het uitgeven van een verklaring dat voor de testperiode ten aanzien van deze aanbieder/dit product wordt afgezien van de handhaving van de regels (internationaal aangeduid als no-action letter).

De financiële toezichthouders betonen zich door de bank genomen gevoelig voor het risico dat zij zichzelf te veel ruimte zouden toe-eigenen. De excepties ten aanzien van de regels of handhavingsinspanningen worden beperkt tot wat binnen de eigen competentie ligt. Zo kunnen financiële toezichthouders in afzonderlijke lidstaten van de EU Bankenunie geen experimenten toestaan op het terrein dat

31 Zie https://asic.gov.au/for-business/your-business/innovation-hub/regulatory-sandbox/ (laatst geraadpleegd op 12 februari 2019).

32 Zie www.afm.nl/nl-nl/professionals/onderwerpen/innovationhub-maatwerk (laatst geraadpleegd op 12 februari 2019).

33 Zie www.fca.org.uk/firms/regulatory-sandbox/sandbox-tools (laatst geraadpleegd op 12 februari 2019). Deze worden vrij breed aangetroffen; Toronto Centre 2017, p. 6-7. 
onder het toezicht van de Europese Centrale Bank (ECB) ressorteert, en dat wordt ook expliciet vermeld. ${ }^{34}$

In de Nederlandse context gaan de gedachten allicht in de richting van het gedogen, een beleidsvariant waarin wetshandhaving eveneens achterwege blijft in situaties waarin dat wel wettelijk geïndiceerd is. Gedogen heeft in de bestuurlijke praktijk vele verschijningsvormen, maar is vooral bekend van het softdrugsbeleid. ${ }^{35}$ Evident is dat gedogen van softdrugs niet bedoeld is om het experimenteren met een nieuw product in een afgescheiden ruimte van tijd en populatie te faciliteren, teneinde de uitwerking van dat product te kunnen testen. Dat is het belangrijkste verschil met de sandbox, waarin juist wel sprake is van proactief onderzoek naar de beste voorwaarden voor de introductie van het nieuwe product. Overigens, de juridische vormgeving van het softdrugsbeleid gaat veranderen en zal in een wettelijk experiment gegoten worden, wanneer het voorstel voor de Wet experiment gesloten coffeeshopketen het Staatsblad bereikt heeft. ${ }^{36}$ Dan neemt het experimenteren de gestalte aan die in de vorige paragraaf beschreven is.

Tevens zijn er bij de sandbox overeenkomsten te herkennen van de situatie waarin vanwege een beginsel van behoorlijk bestuur, in het bijzonder het vertrouwensbeginsel, een afwijking van de wet in stand wordt gelaten. ${ }^{37}$ Ook in de sandbox-praktijk valt uit de communicatie van de betrokken autoriteit het vertrouwen te halen dat de wet niet gehandhaafd zal worden. Juridisch zien we niettemin wel een onderscheid tussen enerzijds het eenmalig, bij wijze van uitzondering corrigeren van het bestuurlijk handelen ten gunste van een burger of bedrijf dat een toezegging ontvangen heeft, en anderzijds het voor een bepaald product bevestigen van een pauze in de handhaving van de letter van de wet. Het opgewekte vertrouwen is voor de onderhavige materie wel zodanig van betekenis, dat we er in de volgende paragraaf op terugkomen.

\section{Sterktes en zwaktes; naar een set vuistregels}

Wanneer de overheid gebruikmaakt van experimenteerbepalingen of een regulatory sandbox entameert om innovatieve producten en diensten toegang te geven tot de markt, zijn er ten minste vier actoren wier belang in de afweging moet worden betrokken: de autoriteit die permissie geeft, de aanvrager of uitvoerder van het experiment, de actoren (burgers en bedrijven) die in de uitvoering met het testen te maken krijgen, en ten slotte de overige aanbieders op dezelfde markt.

34 De ECB staat positief tegenover het experimenteren, maar heeft dat zelf nog niet vertaald naar een zichtbare innovatiehub of sandbox (laatst gezocht op ECB-site; 12 februari 2019). Zie Sabine Lautenschläger (ECB-bestuurslid), 'Digital Na(t)ive? Fintechs and the Future of Banking'. Speech 27 maart 2017, gepubliceerd op www.ecb.europa.eu/press/key/date/2017/html/sp170327_1.en. html (laatst geraadpleegd op 12 februari 2019). Zie over de uitwerking richting EU verder W-G. Ringe \& C. Ruof, A Regulatory Sandbox for Robo Advice (EBI Working Paper Series 2018, nr. 26), p. 45 e.v.

35 H.E. Bröring \& K.J. de Graaf (red.), Bestuursrecht 1, Den Haag: Boom juridisch 2019, p. 620-626.

36 Kamerstukken I 2018/19, 34997, A.

37 Bröring \& De Graaf 2019, p. 416-419. 
Hierna zullen wij voor alle actoren enkele specifieke (juridische) aandachtspunten bespreken, waarmee bij de vormgeving van het experiment rekening gehouden zal moeten worden. In de volgende paragraaf vatten we die dan samen in een set vuistregels voor de vormgeving van het overheidshandelen bij experimenten.

\subsection{Legaliteit}

Wanneer de overheid tot een experiment besluit, zal daartoe vanzelfsprekend op de eerste plaats een deugdelijke basis moeten bestaan. Het experiment kan alleen rechtsgeldig plaatsvinden als er een toereikende wettelijke grondslag bestaat. Aan legaliteitseisen komt in relatie tot experimenten extra gewicht toe omdat experimenten nu eenmaal risico's met zich meebrengen. De betrokkenheid van een democratisch gelimiteerd orgaan bij de totstandkoming van de experimenteerbevoegdheid verschaft een vorm van (democratisch) toezicht op de uitoefening van overheidsgezag, juist omdat er (aanzienlijke) risico's voor burgers aan de orde kunnen zijn. Voor experimenten die terug te voeren zijn op experimenteerbepalingen levert deze eis meestal geen problemen op. Door in het verleden in de wet in formele zin een afwijkingsmogelijkheid te creëren heeft er op dat moment democratische inspraak plaats kunnen vinden over de noodzaak en wenselijkheid om afwijking van de wet mogelijk te maken. Ook bepalen veel experimenteerbepalingen dat de specifieke vormgeving van het experiment bij algemene maatregel van bestuur moet geschieden, en dat die regeling bij het parlement moet worden voorgehangen. ${ }^{38}$ Met het voorgaande is evenwel niet gezegd dat er geen juridische bezwaren kunnen bestaan tegen experimenten die steunen op een niet-onderbroken delegatieketen. Het vermogen om juridische kernwaarden met delegatiebepalingen te dienen, hangt onder andere af van de precisie waarmee die bepalingen de overheidsbevoegdheden afbakenen. Op dat punt heeft de Raad van State zich in zijn recente jaarverslag (nogmaals) kritisch uitgelaten. ${ }^{39}$ Naarmate experimenteergrondslagen ruimer worden geformuleerd, komt evenwel niet de legaliteit als zodanig - in de betekenis van: voorzien in een wettelijke basis - onder druk te staan, maar wel daarmee zeer nauw verbonden waarden die in het navolgende apart besproken zullen worden.

Legaliteitsproblemen in de hier bedoelde zin doen zich bij regulatory sandboxes veel sneller voor, omdat het toezichtsorgaan niet experimenteert op basis van een expliciete daartoe strekkende machtiging van een democratisch gelegitimeerd orgaan. De behoefte tot externe controle op de wenselijkheid en noodzaak van het experiment zal bij de actoren die rechtstreeks bij de sandbox betrokken zijn in de regel niet gevoeld worden. De ontwikkelaar die wil experimenteren, zal in het concrete geval niet zelf een kritische vraag stellen bij de wenselijkheid en noodzaak van het experiment. Het zal dus in de eerste plaats van de zelfdiscipline van de toezichtautoriteit moeten komen om de grenzen van haar bevoegdheid te bewaken. In dat verband zien we dat de toezichthouders wel aan verwachtingenmanagement doen. Zij trachten duidelijk te maken dat het experimenteel benut- 
ten van discretionaire ruimte alleen mogelijk is voor zover die discretionaire ruimte in de wet aan de toezichthouder is toegekend.

\subsection{Rechtszekerheid}

De hiervoor besproken legaliteitseis wordt voor deze materie ook concreet in eisen van rechtszekerheid. Door een expliciete wettelijke grondslag wordt het voor burgers en derde-belanghebbenden mogelijk te achterhalen dat er geëxperimenteerd wordt. De rechtstoestand - of beter: het experiment - is dan kenbaar. Niet alleen voor regulatory sandboxes, maar ook voor experimenteerbepalingen geldt dat zij met deze formele rechtszekerheid op gespannen voet kunnen komen te staan. Experimenteerbepalingen bieden een mogelijkheid om af te wijken van een wet in formele zin zonder dat daarvoor een nieuwe wet in formele zin is vereist. Daardoor ontstaat een diffuse regelgevingsstructuur, die niet bevorderlijk is voor de duidelijkheid en kenbaarheid van het recht.

Wanneer de overheid ruimte maakt voor experimenten met innovatieve producten, kan bij de ontwikkelaar de verwachting ontstaan dat het product ook in de toekomst, nadat het experiment is afgelopen, verkocht of aangeboden mag worden. Naarmate de overheid zich meer als partner in het ontwikkelingsproces opstelt, zal die verwachting groter worden. Voor zover ontwikkelaars van innovatieve producten al juridische bezwaren zullen koesteren tegen het experiment waaraan zij zelf hebben deelgenomen, zullen zij naar alle waarschijnlijkheid vooral gediend zijn met deze materiële rechtszekerheid. In de praktijk is het evenwel goed denkbaar dat na het experiment besloten wordt om het product of de dienst toch niet tot de markt toe te laten. ${ }^{40}$ Dat geldt zeker wanneer een wetswijziging noodzakelijk is om dat mogelijk te maken. De uitkomst dat een product positieve resultaten voor de samenleving brengt, levert nog niet de verplichting op om die evidence ook in wetgeving om te zetten. ${ }^{41}$ Daar komt bij dat voor zowel de regulatory sandbox als experimenten op basis van experimenteerbepalingen kan gelden dat het overheidsorgaan dat het experiment permitteert, zelf niet de definitieve regelgeving tot stand kan brengen. Zolang de betrokken autoriteit aan de ontwikkelaar voldoende duidelijk maakt dat er sprake is van een tijdelijke afwijkingsmogelijkheid die geen garanties biedt voor de toekomst, is de rechtsrelatie op dit onderdeel duidelijk. Dan is in ieder geval gewaarborgd dat er in juridische zin geen legitieme verwachtingen ten aanzien van de periode na het experiment kunnen bestaan. Deelnemers voorzien van een goede risicoparagraaf bij de start van het experiment zorgt dat er duidelijkheid bestaat over de beslissingsruimte na afloop van de vastgestelde try-outperiode.

Voor zover de bezwaren tegen een experiment betrekking hebben op een van de twee hiervoor genoemde dimensies van legaliteit, kunnen die bezwaren worden

40 Zie hierover WRR, Met kennis van gedrag beleid maken (rapport nr. 92), Amsterdam: Amsterdam University Press 2014, p. 39.

41 Zie Jacobs 2018, p. 50; Ringe \& Ruof 2018, p. 55, verwijzen naar 'regulatory capture', een concept dat niet alleen in de context van experimenteren relevant is. Het is ook te verwachten bij living labs, waar co-creatie de norm lijkt te zijn, maar daar troffen we het nog niet als vraagstuk aan; zie T. Maas, J. van den Broek \& J. Deuten, Living labs in Nederland. Van open testfaciliteit tot levend lab, Den Haag: Rathenau Instituut 2017. 
weggenomen door op een andere wijze transparantie te bieden. ${ }^{42}$ Door duidelijk aan te kondigen welke experimenten er worden ondernomen en op welke bevoegdheid het experiment is terug te voeren, blijft inzichtelijk hoe het (objectieve) recht luidt en hoe dit wordt toegepast. Daardoor kan er ook, in ieder geval achteraf, controle worden uitgeoefend op de wenselijkheid van het experimenteren.

\subsection{Rechtsgelijkheid}

Burgers moeten kunnen vaststellen welke regels op hen of op de rechtsrelatie waarin zij treden van toepassing zijn. Dit uitgangspunt voert op de eerste plaats terug op de hiervoor uiteengezette idee dat de uitoefening van overheidsgezag controleerbaar moet zijn. Daarnaast houdt zij natuurlijk verband met het beginsel van rechtsgelijkheid. Deze eis krijgt extra gewicht wanneer op de ene groep burgers in dezelfde omstandigheden andere regels van toepassing zijn dan op de andere groep burgers. In experimentele situaties gaat het daarbij veelal om groepen van een behoorlijke omvang. ${ }^{43}$ De rechtvaardiging voor de behandeling als proefpersoon moet worden gezocht in de voordelen van een bepaalde vernieuwing voor de marktpartijen, voordelen die in het bijzonder ten goede komen aan de consumenten die het experiment moeten ondergaan. Dat laat evenwel onverlet dat ook vanuit dit gezichtspunt op de overheid een verplichting rust om voldoende transparant te zijn.

Daarnaast zal bij de inrichting en uitvoering van een experiment niet alleen rekening moeten worden gehouden met de gelijke behandeling van de burgers die het experiment moeten ondergaan. Ook de positie van de overige aanbieders die actief zijn in de relevante sector en mogelijk niet aan het experiment (kunnen) deelnemen, verdient erkenning. Daarbij zal het veelal gaan om concurrenten van het bedrijf of de ontwikkelaar aan wie het experiment vergund is. Sandboxes en andere experimenten zijn naar de aard beperkt in omvang. Dat is ook logisch omdat de effecten van het nieuwe product nog onzeker zijn en juist daarom eerst wordt geëxperimenteerd. Doordat experimenten naar hun aard in omvang beperkt zijn, kan meestal slechts een beperkt aantal ondernemers in een bepaalde periode tot een experiment worden toegelaten. Veel hangt af van het soort product en het aantal ontwikkelaars, maar selectiviteit zal onvermijdelijk zijn.

De eerste vraag die dan opdoemt, is aan wie de experimenteermogelijkheid moet worden geboden c.q. aan wie die rechtens kan worden geweigerd. Anders gezegd: hoe moeten we de verstoring van het level playing field waarderen? Ook al is het bij wijze van experiment, de autoriteit intervenieert in de markt ten gunste van de testcase-eigenaar(s) en maakt daarmee een onderscheid ten opzichte van de mogelijke concurrentie. Door de permissie aan één concrete aanbieder te verlenen ontstaat een lastig parket ten aanzien van elke vervolgaanbieder van een vergelijkbaar innovatief product. ${ }^{44}$ Voor een uitweg uit dit dilemma zou het leerstuk

44 Zie ook Ringe \& Ruof 2018, p. 43, die de president van de Duitse federale toezichthouder BaFin aanhalen in zijn afwijzing van sandboxes: 'same business, same risks, same rules'. 
van de schaarse publieke rechten als inspiratie kunnen dienen, om welke reden we dat leerstuk hier kort aanduiden.

De Afdeling bestuursrechtspraak van de Raad van State heeft erkend dat er naar Nederlands recht een rechtsnorm bestaat, inhoudende dat bij de toekenning van schaarse publieke rechten aan concurrenten mededingingsruimte moet worden geboden. ${ }^{45}$ Deze rechtsnorm steunt op het gelijkheidsbeginsel en daaruit voortvloeiende transparantieverplichtingen. Zo mogen schaarse publieke rechten in beginsel nooit voor onbepaalde tijd aan één aanbieder worden verleend.

Experimenten zijn naar hun aard en per definitie tijdelijk. Het voldoen aan deze eis moet garanderen dat na verloop van tijd ook concurrenten de rechten in kwestie kunnen verkrijgen. Het recht om als concurrent gedurende de looptijd van het experiment alsnog toegang tot een experiment te krijgen, is alleen goed voorstelbaar bij langlopende experimenten. Daaruit volgt natuurlijk niet dat de looptijd van een experiment verlengd moet worden wanneer dat vanuit het oogpunt van de effectiviteit van het experiment niet noodzakelijk is. Dat laat evenwel onverlet dat, als het gezien de aard van het experiment enigszins mogelijk is, het de voorkeur verdient diverse aanbieders op enig moment de experimentele ruimte te bieden, eventueel in verschillen tranches. Dat zou dan het beste juridisch kunnen worden vormgegeven als aparte beslissingen, getoetst aan vooraf bekende criteria en met eigen voorwaarden. Dat de mogelijkheden om experimenten te begeleiden aan de kant van de autoriteit praktisch beperkt zijn, is niet onbelangrijk en onderstreept het nut van het denken over schaarse publieke rechten als richtsnoer voor de vormgeving van experimenten. Andere eisen die aan de verlening van schaarse publieke rechten worden gesteld, zouden ook op experimenten kunnen/moeten worden toegepast. Zo mag van de overheid die tot het instellen van een experiment besluit, worden verwacht dat zij ten aanzien van alle potentiële geïnteresseerden in het experiment een passende mate van openbaarheid in acht neemt met betrekking tot het openstellen van het experiment, de toewijzingsprocedure, het aanvraagtijdvak en de toe te passen selectiecriteria. Op al deze onderdelen moet tijdig voorafgaand aan de start van de toewijzingsprocedure duidelijkheid worden geschapen, door informatie over deze aspecten bekend te maken via een zodanig medium dat potentiële gegadigden daarvan kennis kunnen nemen.

Uiteindelijk moet echter ook worden onderkend dat experimenteren vaak tot verschillende vormen van ongelijke behandeling zal leiden. Dat geldt ook voor de mogelijke ongelijke behandeling van concurrenten. Zolang de gevolgen beperkt blijven en er geen onomkeerbaar voordeel voor de ene ondernemer ten opzichte van de andere ondernemer ontstaat, wordt die ongelijke behandeling door de verwachte uitkomsten gerechtvaardigd.

\subsection{Verantwoordelijkheid}

Tot besluit moet ook aandacht worden besteed aan de kwestie van de verantwoordelijkheid. In het bijzonder bij de case-by-case arrangementen in de sandboxme- 
thode worden alle betrokken partijen al snel deelgenoot in het experiment. Dit kan leiden tot vervaging van de verantwoordelijkheden tussen toezichthouder en ontwikkelaar. ${ }^{46}$ Uiteindelijk kan die vervaging voor de toezichthouder zelfs aansprakelijkheidsrisico's met zich brengen. ${ }^{47}$ Uiteraard zal de aanname vaak zijn dat de toezichthouder alleen maar toestemming geeft als de gevaren voor de consument of burger in het experiment door de aanbieder van het product of de dienst zijn afgedekt. ${ }^{48}$ Maar experimenteren blijft riskeren en deze risico's worden door de toezichthouder of andere autoriteit bewust aanvaard. ${ }^{49}$ De verantwoordelijke autoriteit doet er dan ook verstandig aan het experiment niet alleen voldoende indringend te monitoren, maar ook vooraf een arrangement te eisen voor afwikkeling van ongelukken. ${ }^{50}$ Deze en andere zaken regelt men bij voorkeur proactief in de vorm van voorwaarden in het vergunnende besluit. En ook hier geldt dat een voldoende duidelijke communicatie over het experiment dat wordt ondernomen en de daarmee verbonden risico's ervoor zorgt dat de consument - de derde in de rechtsverhouding tussen autoriteit en experimenthouder - zijn gedrag op de experimenten kan aanpassen.

Wanneer experimenten plaatsvinden op basis van wettelijke experimenteergrondslagen doet de vervaging van verantwoordelijkheden zich minder snel voor. Experimenteerbepalingen kennen altijd een duidelijke afbakening van verantwoordelijkheden en bieden door de wettelijke grondslag noodzakelijkerwijs een zekere mate van transparantie. Toch is ook hier de genoemde proactiviteit aanbevelenswaardig, evenals een actieve monitoring van het experiment. Het voorschrift in de Aanwijzingen voor de regelgeving dat een experiment geëvalueerd moet worden, komt ons in dit verband minimalistisch voor en is niet toereikend om eventuele risico's die zich gedurende het experiment aandienen, tijdig te ondervangen. Datzelfde gaat op voor mogelijke incidenten tijdens het experiment die tot voortijdig stoppen van het experiment zullen moeten leiden. Dergelijke (mogelijke) incidenten dienen voorafgaand aan het experiment te worden beschreven met daarbij passende handelwijzen voor de beëindiging.

\subsection{Tussenbalans}

Hierboven zijn diverse aspecten besproken van de vraag in hoeverre het experiment verenigbaar is met de rechten van de burgers en bedrijven die het experi-

46 Aan de 'institutionalized dialogue' zitten overigens niet alleen maar nadelen. Zie Ringe \& Ruof 2018, p. 36-37 en 39-40.

47 Art. 1:25d Wft regelt een vrijwaring voor de financiële toezichthouders. Die sluit de uit experimenten voortkomende aansprakelijkheid niet volledig uit. Bovendien is de vrijwaring van de autoriteiten en hun bestuursleden niet afdoende om behoorlijkheid te betrachten ten aanzien van potentieel gelaedeerden. Zie verderop in de hoofdtekst voor wat er nog bij zou moeten komen.

48 AFM/DNB, Meer ruimte voor financiële innovatie, Amsterdam 2016, p. 5-6; FCA, Regulatory Sandbox, 2015, p. 21-22.

49 Dit aandachtspunt is geïnspireerd door Hanebury 2006, p. 54. Zie ook Wagner 2018, p. 3.

50 Vgl. de plicht tot verzekeren in art. 7 Wet medisch-wetenschappelijk onderzoek met mensen (WMO). In bijzondere gevallen kan zelfs worden overwogen dat de experimenthouder niet alleen de gelaedeerde moet compenseren, maar ook de autoriteit moet vrijwaren en daartoe een passende assurantie afsluiten. 
ment moeten ondergaan of daarmee in aanraking komen. De overheid heeft, ook wanneer het experiment in de horizontale verhouding tussen een private ontwikkelaar en een groep burgers plaatsvindt, de verantwoordelijkheid om de rechten van haar burgers te beschermen. Die verplichting geldt zo mogelijk nog sterker zodra grondrechten in het geding zijn. Daaruit volgt overigens niet dat experimenten in dat geval helemaal niet meer mogen plaatsvinden, maar wel dat burgers of consumenten moeten worden gewezen op het experiment en de daarmee samenhangende gevaren, en dat hun positie in het experiment van bepaalde waarborgen voorzien is, zoals de garantie dat het experiment voldoende gemonitord wordt.

Experimenteren past bij een samenleving die responsiever wordt, waarin de overheid probeert adaptieve wetgeving te maken die zich aan veranderende omstandigheden kan aanpassen en in staat is om maatwerkoplossingen te bieden als die voor groepen rechtssubjecten - burgers en bedrijven - voordelig (kunnen) uitwerken. Hiervoor hebben wij al een aantal keren opgemerkt dat het vergroten van de responsiviteit in de vorm van het creëren van experimenteerruimte noodzakelijkerwijs tot meer transparantie moet leiden, om gelijkheid, legaliteit en rechtszekerheid te kunnen blijven waarborgen. Transparantie is in staat om vele juridische bezwaren en mogelijk daaruit voortvloeiende tekortkomingen in de verwezenlijking van andere rechtsstatelijke uitgangspunten te corrigeren. Daarbij kent de eis van transparantie voor iedere actor, betrokken bij het experiment, een eigen verschijningsvorm. Andere auteurs hebben betoogd dat experimenten voornamelijk op basis van het evenredigheidsbeginsel moeten worden beoordeeld. ${ }^{51}$ Daaraan kleeft echter een praktisch bezwaar. Doordat er bij experimenteren nog zoveel onduidelijk is, zal slechts in een zeer beperkt aantal gevallen voorafgaand aan het experiment zinvol beoordeeld kunnen worden of een experiment wel of niet evenredig is. Transparantie voorafgaand aan het experiment biedt een effectievere waarborg. Dat sluit natuurlijk niet uit dat men na afloop van het experiment tot de conclusie komt dat het experiment onevenredig lang heeft geduurd of tot een onevenredige inbreuk op grondrechten heeft geleid.

Tot nu toe is echter een wezenlijk, aan experimenten verbonden probleem onbesproken gebleven. Voor sommige experimenten geldt dat op basis van methodologische argumenten de door ons gepropageerde transparantie problematisch is. $\mathrm{Bij}$ experimenteren volgens sociaalwetenschappelijke maatstaven wordt immers het uitgangspunt gehuldigd dat de proefpersonen niet mogen weten of zij bij de experimentpopulatie behoren of in de controlegroep zitten. ${ }^{52}$ Zou dat wel bekend zijn, dan wordt verondersteld dat de proefpersonen daarop gaan reageren, en dat verlaagt de waarde van de uitkomsten tot ongeveer nul. Het is niettemin normaliter wel duidelijk voor de proefpersonen dat zij deelnemen aan een wetenschappelijk project, alleen in welke hoedanigheid is onbekend. Tegelijkertijd geldt dat van-

51 O.a. Ranchordás 2018, p. 35.

52 De onderliggende vooronderstelling wordt voor het specifieke geval van nudging weer betwijfeld door H. Bruns e.a., 'Can Nudges Be Transparant and Yet Effective?', Journal of Economic Psychology (65) 2018, p. 41-59. 
uit de onderzoeksethiek de bewustheid van deelname aan een experiment een belangrijk onderdeel is van de ethische aanvaardbaarheid van het experiment. ${ }^{53}$

De oplossing dient te worden gezocht in maatwerk per experiment en - niet onbelangrijk - voor de beperkte duur van het experiment in de mate waarin dat voor de gewenste factfinding onvermijdelijk is. ${ }^{54}$ De voor het onderzoek wenselijke heimelijkheid strekt zich wat ons betreft niet uit tot het gegeven dat in een bepaalde sector experimenten kunnen voorkomen. Dit is de minimale transparantie die de overheid in ieder geval altijd zou moeten betrachten. In beginsel valt ook het gegeven dat in een sector aan een concreet aangeduide actor een experiment toegestaan is, onder hetzelfde regiem, tenzij zeer zwaarwegende omstandigheden zich daartegen verzetten. In dat opzicht is bijvoorbeeld de praktijk van de Britse FCA te verkiezen boven die van onze nationale financiële toezichthouders. De FCA publiceert de namen van de bedrijven waaraan een experiment gegund is, terwijl DNB/AFM deze interactie met een aanbieder tot toezichtvertrouwelijk domein verklaard heeft. ${ }^{55}$ Dat is niet de goede default modus en wanneer die door een geheimhoudingsplicht ingegeven is (art. 1:89 van de Wet op het financieel toezicht (Wft)), is het wenselijk daarop een uitzondering te kunnen maken. Ten slotte moet ook aan de objecten van onderzoek duidelijk zijn dat zij zich aan de experimentele context kunnen onttrekken, ook al wordt in gevallen waarin dat methodisch geïndiceerd is, niet bekend gemaakt of men tot de proefpopulatie of de controlegroep behoort.

\section{Vuistregels}

Het voorafgaande kan concluderend worden samengevat in een set vuistregels. Daarmee wil niet gezegd zijn dat inachtneming daarvan altijd leidt tot eenduidige uitkomsten of enkelvoudige afwegingen. Daarvoor is de vormgeving van de experimenten te divers en zijn de afwegingen bij experimenteren in real-life situaties te complex. ${ }^{56}$ Dat gezegd hebbende moet bij de vormgeving van experimenten met het navolgende rekening worden gehouden.

Allereerst geldt dat de overheidsinstantie die beslist tot het instellen van een experiment eerst haar eigen positie voldoende zal moeten afbakenen. Dat bete-

53 Zie bijv. S. Dench e.a., An EU Code of Ethics for Socio-Economic Research (Institute for Employment Studies report 412), Brighton 2004, p. 63 e.v.; WRR 2014, p. 74. Enigermate verontrustend is dat de AFM in het hiervoor aangehaalde document daarover niets vermeldt; supra voetnoot 41, wat overigens niet uitsluit dat in concreto wel disclosure als default wordt gekozen. Zie de FCA Default standards for sandbox testing parameters, onder: customer safeguards via www.fca.org. uk/publication/policy/default-standards-for-sandbox-testing-parameters.pdf (laatst geraadpleegd op 12 februari 2019). De WMO laat in art. 4 t/m 6 zien hoeveel gewicht toekomt aan bekendheid met het experiment. Men zou dit een bijzonder geval kunnen noemen, maar dat doet niet af aan de stelling dat transparantie ten opzichte van de deelnemers aan een experiment in real life niet geheel achterwege kan blijven en om maatwerk vraagt.

54 Vgl. Kamerstukken I 2017/18, 34838, C, p. 5 over het wel/niet stellen van de eis dat proefvoertuigen zonder bestuurder herkenbaar zijn.

55 AFM/DNB 2016, p. 7.

56 Analoog met de nuancering van rechtsstatelijke bezwaren al naar gelang de consequentie van het experiment voor het individu, in: WRR 2014, p. 69-73. 
kent dat zij er zorg voor moet dragen dat voor de beoogde modaliteit van het experiment een bevoegdheid bestaat, en dat als gebruik wordt gemaakt van een bestaande bevoegdheid binnen de grenzen van die bevoegdheid wordt gehandeld. Daarnaast verdient het aanbeveling om vooraf duidelijkheid te verschaffen over de onderscheidenlijke verantwoordelijkheden van de overheid die experimenteerruimte laat en degene die het experiment zal uitvoeren (de experimenthouder).

Los van de verantwoordelijkheden ten aanzien van de eigen positie heeft de overheid ook een aantal verantwoordelijkheden ten opzichte van de experimenthouder. Die verantwoordelijkheden brengen hier vooral de eis met zich mee dat zij voorafgaand aan het experiment (samen met de experimenthouder) helderheid verschaft omtrent de voorwaarde(n) waaronder het experiment een succes is en/ of kan worden verlengd. Daarbij verdient het aanbeveling te expliciteren dat er geen binding bestaat ten aanzien van toelating van het product of de dienst na afloop van het experiment.

Daarnaast moet de overheid ook het belang van derden borgen, waartoe zowel burgers die het experiment ondergaan als (potentiële) concurrenten van de experimenthouder kunnen worden gerekend. In het licht van de belangen van deze derden zal het experiment aan een aantal inhoudelijke eisen moeten voldoen. Ten eerste zal de overheid voorafgaand aan het experiment moeten waarborgen dat de tijdsduur van het experiment duidelijk is afgebakend. Daarbij mag het experiment nooit langer duren dan voor het bereiken van de doelstellingen noodzakelijk is. Ten tweede zal de overheid er zorg voor moeten dragen dat er zo veel transparantie wordt betracht als het experiment toelaat. Dat betekent in ieder geval dat altijd bekend zal moeten worden gemaakt dat er op een bepaald beleidsterrein experimenten (kunnen) plaatsvinden, en aan wie op een bepaald moment permissie is verleend om een experiment te houden. Voorafgaand aan de selectie van de experimenthouder(s) zal duidelijk moeten worden gemaakt hoe de toewijzingsprocedure zal verlopen en op basis van welke criteria toelating tot het experiment mogelijk is. Daarnaast is het in de meeste gevallen wenselijk openheid te betrachten omtrent de vraag welke burgers als testobject/-subject met het experiment in aanraking zullen komen. Er mogen nooit meer burgers als testsubject worden gebruikt dan voor het experiment strikt noodzakelijk is. Tegelijkertijd geldt ook dat zo veel mogelijk aanbieders toegang tot het experiment moeten krijgen. Deze beide belangen zullen in een concreet geval tegen elkaar moeten worden afgewogen. Daarbij zullen de negatieve consequenties van het experiment voor de (grond)rechten van burgers doorslaggevend zijn. In dat licht verdient het aanbeveling burgers duidelijkheid te bieden over mogelijkheden om zich aan het experiment te onttrekken.

Naast de overheid zal voor een juridisch toelaatbaar experiment ook door de experimenthouder aan een aantal eisen moeten worden voldaan. Van de experimenthouder mag worden verwacht dat hij zorg draagt voor een concrete omschrijving van het experimentele product, de testvraag, de testomgeving en de datacollectie. Daaronder moet ook worden verstaan dat hij mogelijke exit-strategieën beschrijft. Daar komt bij dat het voor de experimenthouder verstandig is om samen met de overheid vooraf helderheid te verkrijgen omtrent de aansprake- 
lijkheid voor eventuele schade die door het experiment kan ontstaan en de daarvoor af te sluiten assurantiecontracten.

\section{Afsluiting}

We komen tot een afsluitende samenvatting van onze bijdrage. In het voorliggende artikel is verslag gedaan van een onderzoek naar de verschillende verschijningsvormen van een tijdelijke bypass van bestaande rechtsnormen ten behoeve van innovatie. We hebben vooral die instrumenten beschreven die toegepast worden om innovatieve producten in het echte leven te testen, wat zonder die bypass niet of niet zonder meer verenigbaar zou zijn met het geldende recht. Een theoretisch model om de praktische verschijningsvormen te ordenen vormt de prelude voor een beschrijving en kritische beoordeling van wettelijke experimenteerbepalingen en regulatory sandboxes. De beoordeling in het licht van de geldende normen en beginselen mondde uit in een set vuistregels, met behulp waarvan een vergunnende overheid haar bypass kan aanleggen.

De slotsom luidt dat een genuanceerde combinatie van de diverse beschreven maateregelen tot het beste experiment voert. Het maakt mogelijk dat het doel om innovaties flexibel tegemoet te treden gerealiseerd wordt met overheidshandelen, dat nochtans juridisch spannend is. Net als voor de te regelen materie geldt immers voor het toepassen van deze flexibele vorm van reguleren dat die niet volkomen risicoloos is. Toepassing van de vuistregels zou naar onze overtuiging kunnen assisteren bij goede besluitvorming, zodat het overheidshandelen een stootje zal kunnen verdragen. 